\title{
Advance Application of Wind Energy and Wind Power in Louisiana
}

\author{
Yucheng Liu*, Stefan J. Chu
}

Department of Mechanical Engineering, University of Louisiana at Lafayette, Lafayette, LA, 70503, USA

\begin{abstract}
In recent years, many nations have been creating newer, more efficient sources of energy and appropriate legislation with which to drive these new economic frontiers. Wind power or wind energy is one of those energy sources that is used for generating electricity and helping us up to a large extent to cope with humankind's increasing needs and demands of electricity. Countries in Europe, parts of Asia, and the Americas, such as the U.S., China, and Germany, are in the forefront of this technological and environmental revolution, and, as a result, have seen large support and success in the endeavor for clean energy. Modern variable-axis wind turbines have been and are continuing to be very popular and moderately efficient forms of this clean energy. Changes in American energy policy have facilitated the transition towards new energy systems, including wind energy; however, Louisiana - which is largely an oil and gas state - is not showing much, if any, initiative to capitalize and integrate towards these energy sources. An outline of the economic growth of Europe, China, and the whole U.S.A will show that this industry, supported by manufacturers and labor sources, is a viable and profitable form of clean energy.
\end{abstract}

Keyword Wind Energy, Wind Power, Wind Technology, Louisiana, Green Energy

\section{Introduction}

Wind energy is a rapidly expanding field of study which concentrates its efforts to generating electricity by capturing the power within kinetic air flow. Modern trends being adopted in Europe, parts of Asia, and the United States are paving the way to an era based on renewable energy rather than carbon-rich fossil fuels. The US is attempting to follow in this pattern by implementing clean energy legislation and mandatory emission standards; however, without a strong, well-established economy and the relative industry to drive these plans, Louisiana could fall behind our sister states in the race to own and capitalize on this promising market.

With that in mind, what exactly is wind energy and how can we generate it? Simply, wind energy is generated by fan blades attached to a gear box that rotate under the influence of natural wind patterns. This will spin a shaft which is attached to a generator in order to create electricity to power a light bulb, farm, small town, or city block depending on the size and location of the turbine, or turbines in the case of a wind range. Humans using wind as a form of energy is recorded as long as a 1000 years ago; farmers could mill grains, pump water, cut lumber, and a variety of other laborious tasks due to the physical energy acquired with the early turbine. Following the rush of electricity in the $19^{\text {th }}$

* Corresponding author:

yucheng.liu@louisiana.edu (Yucheng Liu)

Published online at http://journal.sapub.org/ijee

Copyright (C) 2012 Scientific \& Academic Publishing. All Rights Reserved century, the early variable-speed wind turbines had no economical way of either interconnecting to power grids or supplying power for the many new appliances that began to fill farm households[1].

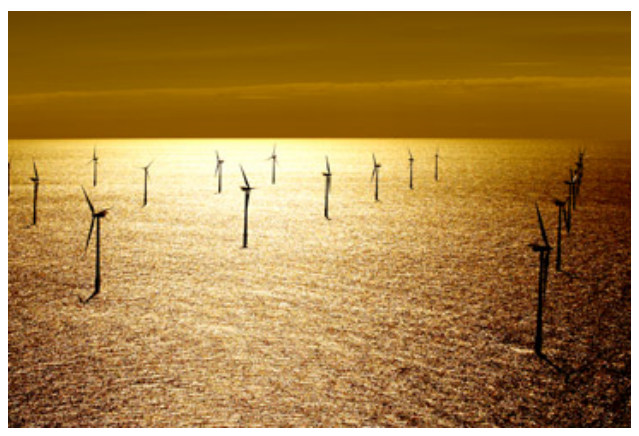

Figure 1. Offshore Wind Turbines.

Many advances were made during the 1800's due to the rapid expansion of America to the Pacific Ocean and a growing national agricultural demand. Around the time of Edison and Tesla, electrical generation and motor technology breakthroughs were widely published and the $60 \mathrm{~Hz}$ $\mathrm{A} / \mathrm{C}$ voltage system forced the variable speed horizontal axis turbines out of common use-save for the farmers who relied on them despite their poor efficiency. With these new generators working in conjunction with variable speed fan blades and gear boxes, Americans and Europeans using this technology could then send the energy generated from the turbines back into the grid[1]. Wind energy became a new commodity and efforts in mostly centered in Europe increased the support and usability of this new technology. 


\section{Advantages of Wind Energy}

Compared to other forms of energy, the wind energy provides following advantages.

The wind energy is a safer and cleaner source of energy which generates electricity without releasing any harmful pollutants or gases as by products.

Wind energy is also one of the cheapest forms of energy available today and therefore it can be extensively used in rural areas by poor farmers. Table 1 lists and compares the price of wind energy and other energy forms.

Wind energy is an efficient renewable energy, because it does not involve the use of any fossil fuels or nonrenewable sources of energy like natural gas, coal or oil.

Wind energy is a green energy because it is causes no carbon emissions therefore creating less pollution.

Wind is a never ending resource, therefore power cuts and power failures are almost nonexistent in areas that rely upon wind power to generate electricity.

With the use of larger electric grids, higher amount of electricity can be generated, which thus makes electricity accessible to a larger number of households in the vicinity.

Table 1. Total cost of electricity production per kWh[2]

\begin{tabular}{|c|c|}
\hline Energy Source & Cost per kWh \\
\hline Nuclear & $\$ 0.04$ \\
\hline Hydro & $\$ 0.03$ \\
\hline Coal & $\$ 0.04$ \\
\hline Natural Gas & $\$ 0.10$ \\
\hline Petroleum & $\$ 0.10$ \\
\hline Other Renewables & $\$ 0.15$ \\
\hline Wind & $\$ 0.08$ \\
\hline
\end{tabular}

\section{Modern Design of Variable Speed Horizontal Axis Wind Turbines}

Most modern wind turbines are under the class of variable-speed, horizontal axis. This means two major things: that the blades do not spin at the same speed all of the time but rather they vary according to the relative intensity of wind speeds, and that the blade's axis of rotation is horizontal. The founding of variable voltage conversion in the 1970 's propagated a large growth in wind turbine farms and the potential for "unlimited" energy. Though this is impossible, the efficiency of modern turbines is startling compared to the capacities seen previously.

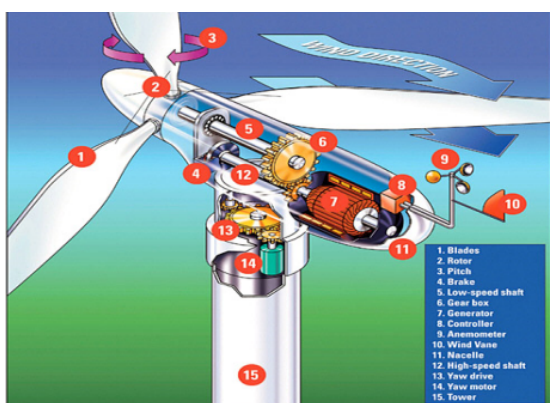

Figure 2. Internal Components of Modern Turbine[5]

\subsection{Major Components}

Blades: Hit by the moving wind and convert the kinetic wind into rotational shaft energy. Effective Design has shown that a 6:7 tip speed/wind speed ratio is optimal. In order to increase power output, larger components must be built; however, weight and wear become major factors with large scale design.

Hub: Serves as the center axis for the rotating blades. Contain rotor and flange bolts which allow adjustment of blades.

Main Shaft: Turns the gear box and generator.

Gearbox: The defining feature of the variable axis wind turbine, which allows for shifting of gear ratios to enhance the efficiency of the generated electricity. Usually a combination of two gear sets to allow at most one ratio of $1: 25$, or two 1:5 ratio conversions.

Generator: Housed inside the Nacelle, receives rotational energy and creates a rotating magnetic field is produced inside a set of windings called the stator[3].

\section{Modern Market for Wind Energy}

\subsection{European Standard}
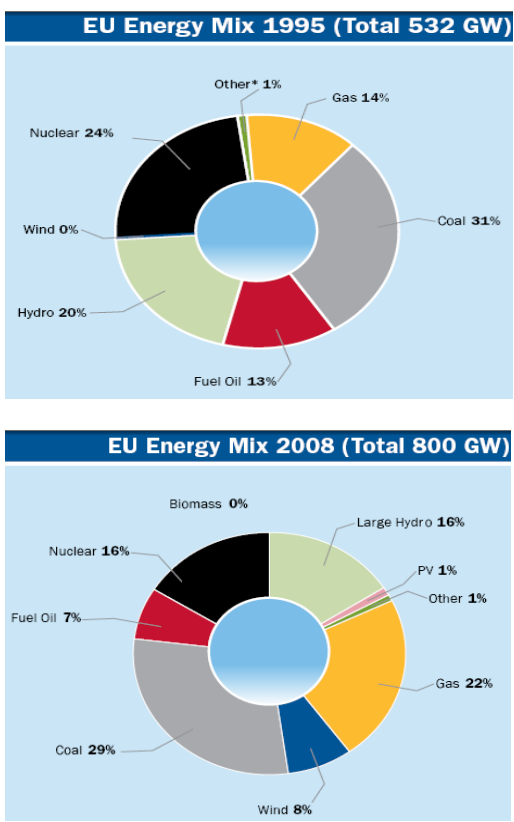

Figure 3. $+7 \%$ Growth of Output from Wind Turbines in Mega-Watts from 1995 to 2000 in European Union.

By the end of 2000, almost 17500 MW of electricity generating wind turbines were operating in over 50 countries. Of these, over $70 \%$ (12800 MW) were installed in the European Union[4].

The creation of support systems through kilowatt-hour (kWh) feed-in tariffs has significantly boosted wind power installations and similar investments. Turbine manufacturing industries also benefited from these changes. Other European countries that have chosen not to utilize these tariff systems have been less successful, despite their advantageous wind potential. Germany, Spain, and Denmark are leading the rest of the European countries which supply and maintain an efficient system of wind energy creation. In 
employment terms, the wind industry has created some 25000 new jobs in Germany. The industry's 1999 turnover amounted to the record of 2 billion Euros, including exports which have grown to almost $20 \%$ of total sales[4].

According to the European Commission's "EU Energy Outlook to 2020 " study, the use of electricity is expected to expand by $1.7 \%$ per year over the period 1995-2020. Total power capacity requirements are expected to increase by some $300 \mathrm{GW}$ during this period and a similar amount of new capacity will be required for the replacement of decommissioned plants. Thus, approximately $600 \mathrm{GW}$ of new plants over the 1995-2020 period will be constructed and put into use. On the same note, the European Parliament in 1998 has set the goal of "doubling Renewable Generation in Europe from $6 \%$ of the gross energy consumption to $12 \%$ by 2010 . It is estimated that this development will have the following effects[4]:

Total avoided fuel cost (1997-2010) 21 billion Euros.

Half a million new jobs created.

Reduction of fuel imports by $17.4 \%$ compared to 1994 .

Reduction in $\mathrm{CO}$ emissions up to 402 million tons per year compared to 1997 "

\subsection{Asian Standard}

China and India are in the forefront of Asian nations which are increasing their funding of wind energy programs. Chinese energy officials predict some of the largest business growth in the next 2-5 years to be in the energy market, with a significant portion coming from wind energy related industries. In 2007, 24 billion Yuan (\$3.28 billion US, approximately) was invested in the energy sector which spurred an increased growth in these industries and created a localization of resources in the provinces of China (Schwartz and Hodum 2008). The effects of localization could not previously be seen in Europe because not only are the nations of Europe close together, but also these companies were physically obliged to sell and buy from each other so that their industry could grow

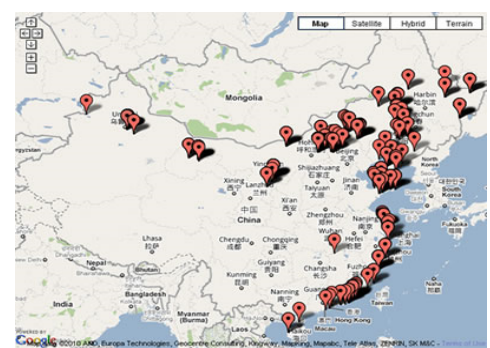

Figure 4. Chinese Installed Wind Farms[7].

Chinese efforts in wind energy are increasing at such a rapid rate; however, that the legislations requiring $70 \%$ Chinese components[8] in the process may be uplifted to promote more growth in this industry. Zhang Guobao, head of the National Energy Administration (NEA), was quoted as saying that domestic wind equipment manufacturers are ready for joining international competition. If the aforesaid requirement is removed, overseas wind turbine producers will gain full access to the fast-developing market. China is expected to have $30 \mathrm{GW}$ of installed wind power capacity by 2010 and add nearly $10 \mathrm{GW}$ of wind power capacity each year from 2010 to 2020. In 2009, Chinese companies will produce as much as 83 percent of the domestically used wind power equipment, predicted Shi Pengfei, vice president of the Chinese Wind Energy Association.

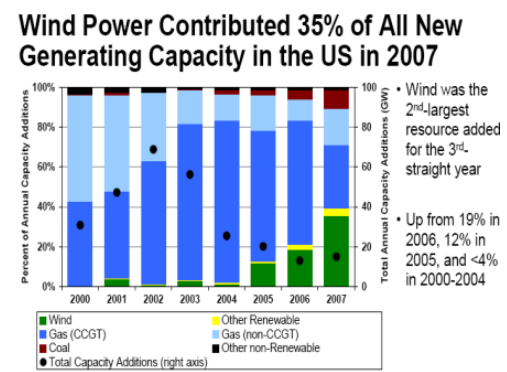

Figure 5. Energy Growth in all sectors, US 2000-2007[9].

\subsection{American Standard}

In 2008 , the U.S. wind energy industry brought online over 8,500 megawatts (MW) of new wind power capacity, increasing the nation's cumulative total by $50 \%$ to over $25,300 \mathrm{MW}$ and pushing the U.S. above Germany as the country with the largest amount of wind power capacity installed. The new installations place the U.S. on a trajectory to generate $20 \%$ of the nation's electricity by 2030 from wind energy as long as the industry continues to garner long-term policy support[10].

The U.S. market for small wind turbines - those with capacities of $100 \mathrm{~kW}$ and under - grew $78 \%$ in 2008 with an additional 17.3 MW of installed capacity. This growth was largely attributable to increased private equity investment for manufacturing, which allowed equipment supply and availability to increase[10].

Notwithstanding these developments, regulatory delays, turbine supply shortages, high and uncertain project costs, and public acceptance concerns have hampered progress in the offshore wind sector[11].

The manufacturing of wind turbines and components in the United States remains somewhat limited, in part because of the continued uncertain availability of the federal PTC. As domestic demand for wind turbines continues to surge, however, a growing number of foreign turbine and component manufacturers have begun to localize operations in the United States, and manufacturing by U.S.-based companies is starting to expand[11].

With the OPEC oil embargo as backdrop, the modern wind industry got its start in the U.S. in the 1970s. The Federal renewable energy research program was launched in 1974, one year after the embargo, and AWEA was incorporated in the same year. Federal and State investment tax credits drove a flurry of activity in the early 1980s that would recede late in the decade due to massive cuts in government funding. The average turbine size in the 1980s was $100 \mathrm{~kW}$; and power cost more than 30 cents $/ \mathrm{kWh}$ due to mechanical difficulties and low equipment availability rates[10]. Of course these numbers are lower now due to improvements in the industry and mechanical design. 

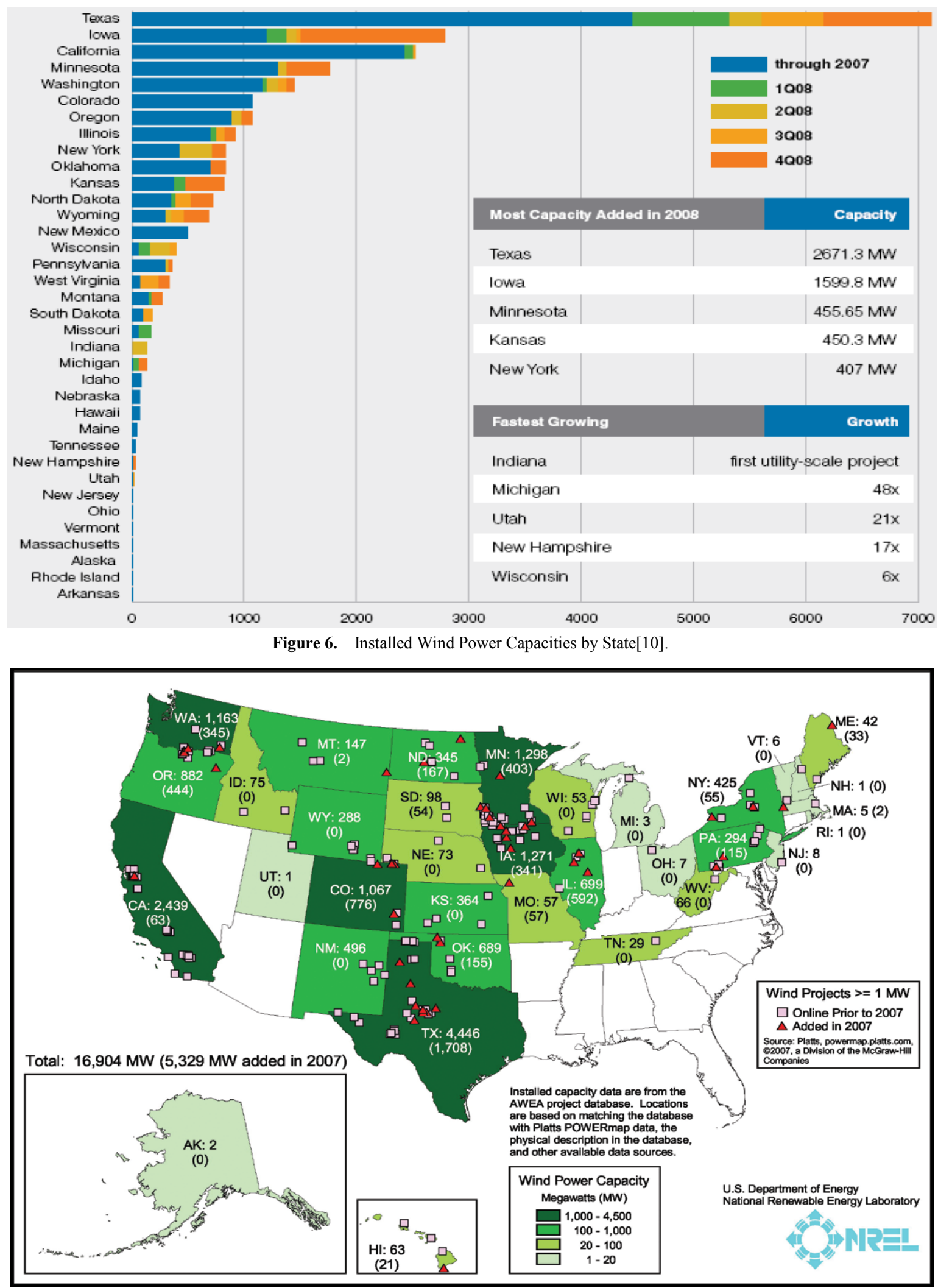

Figure 7. Installed Wind Power Capacities by State-Geographical[9].

The AWEA 2009 Annual Wind Energy Report comments on recent legislation involving wind energy:

"On February 17, 2009, President Obama signed into law The American Recovery and Reinvestment Act (ARRA) of
2009. The legislation includes a three-year extension of the production tax credit (PTC) and a new program that allows renewable energy developers the option of forgoing the PTC and instead securing a grant from the Treasury de- 
partment in the amount of a $30 \%$ investment tax credit (ITC). This program to help monetize renewable tax credits is considered critical for the wind industry to continue its growth in the face of the economic downturn, which has dramatically reduced the ability to secure value for renewable tax credits."

To help consumers buy small wind systems, the recovery bill also removed the $\$ 4,000$ cap on the small wind ITC. Small wind investors are now allowed to claim a full $30 \%$ ITC for qualified small wind energy property. The new law authorizes an additional \$1.6 billion of new clean renewable energy bonds to be distributed to tribal governments, public power providers, and electric cooperatives to finance facilities that generate electricity from renewable resources. It also provides a new $30 \%$ credit for investment in qualified property used in a "qualified advanced energy manufacturing project"[12].

Nowadays, with the significant development of wind technologies and growing applications of wind turbines around the world, the globally total nameplate capacity of wind power reaches $194,400 \mathrm{MW}$. The top 10 wind power countries are listed in Table 2.

Table 2. Top 10 wind power countries (February 2011) [17]

\begin{tabular}{|c|c|}
\hline Country & Wind power capacity \\
\hline China & $44,733 \mathrm{MW}$ \\
\hline United States & $40,180 \mathrm{MW}$ \\
\hline Germany & $27,215 \mathrm{MW}$ \\
\hline Spain & $20,676 \mathrm{MW}$ \\
\hline India & $13,066 \mathrm{MW}$ \\
\hline Italy & $5,797 \mathrm{MW}$ \\
\hline France & $5,660 \mathrm{MW}$ \\
\hline United Kingdom & $5,204 \mathrm{MW}$ \\
\hline Canada & $4,008 \mathrm{MW}$ \\
\hline Denmark & $3,734 \mathrm{MW}$ \\
\hline
\end{tabular}

\section{Impacts of Wind Energy Production in Louisiana}

Europe, especially Spain, Denmark, and Germany, have seen tremendous growth and prosperity in the wind energy sectors. Not only has it created jobs in manufacturing, but also in operations management and construction of turbines. Other areas of the world have also seen productive results from investment and funding of wind energy. China's projected growth in wind related industries is huge, while India has a developing program aimed at promoting growth and industry in wind technology. The U.S. has passed legislation promoting growth in the renewable energy field. And still, Louisiana is shaded completely white on the Energy Department's map of states with installed wind capacity. Is it because of the massive amount of lobbying pull from oil and offshore industries? Is it because nobody has tried to bring this topic up to Louisiana Government? Is Louisiana even usable for wind capacity, and if so, where? These are not unique questions nor are they unasked ones. Louisiana has seen interest in wind energy, but it has never seen wind energy in force.

\subsection{Environmental}

Studies performed in Denmark showed that locals preferred wind energy when it was built offshore but disliked turbines placed on land. The aesthetic quality of the land is compromised due to onshore wind farms. However, the reduction of electricity costs and the distance of offshore turbines were accepted and sought after. Louisianans are accustomed to offshore oil and gas rigs, so wind turbines shouldn't be too foreign. Waterfowl of course suffer risk of injury from rotating fan blades, but the DNR has stated that this risk is minimal due to the slower rotational speeds of modern turbines.

\subsection{Educational}

Current efforts in State Legislature are pushing for lowered spending in Higher Education sectors. This includes the removal of TOPS recipients who fall under high income brackets, the lowered funding of remedial courses offered at public universities-which links to community colleges throughout Louisiana, and the cutting of research grants in certain fields. What the legislature is trying to push for is a greater amount of students beginning at technical colleges and moving onto public universities if they want to continue with a formal degree. However, this is good for wind technology because it will allow access to a greater number of students who are pursuing a technical degree and may be interested in the production, manufacturing, or operation of wind turbine equipment. Hopefully this will begin a reaction in Louisiana students to pursue at least a high school diploma in order to advance towards a technical degree, perhaps in the wind energy sector.

\subsection{Economic}

The economics of a 50-MW wind farm at a wind site with average wind speed of 13-17 $\mathrm{mph}$ (class 4). Figures are indicative only[13].

Project size: $50 \mathrm{MW}$

Capital cost: \$65 million (\$1.3 million per MW)

Annual power production (assuming 35\% capacity factor) 150 million $\mathrm{kWh}$

Financing: $60 \%$ debt, $40 \%$ equity

Annual gross revenue: $\$ 6$ million (assuming power purchase price of 4 cents / $\mathrm{kWh}$ )

Expenses:

Debt: $60 \%$ (15 years at 9.5\%)

Distribution $22 \%$

Operation and maintenance (8\%)

Land, property taxes, or rent $5 \%$

Mgt fees, insurance 5\%

Tax credit and depreciation:

5 -year depreciation on wind equipment

$1.5 \mathrm{c} / \mathrm{kWh}$ credit adjusted for inflation during first ten years of operation

The economic breakdown for wind turbines is as follows: 
The larger the turbine blades, the larger the energy output and effective generation. Starting with large turbines reduces the time between initial investment and capital growth. Secondly, since there is no fuel cost and low maintenance costs for wind turbines, most of the funding is in initial investment and installation. Over the last 15 years, the direct cost (cents $/ \mathrm{kWh}$ ) of wind power has fallen $85 \%$, and, in some cases, is competitive with coal and natural gas power[14]. These numbers are continuing to fall with newer trends in manufacturing and maintenance.

In 1979, The Department of Energy deemed Louisiana as having significant potential for wind energy; however, they also stated that large economic and bureaucratic obstacles must be overcome in order for that to happen. A 1981 Louisiana Department of Natural Resources (DNR) report, "Evaluating Wind Energy Potential in Louisiana" by Mike French outlines that onshore Louisiana has little to no usability for wind turbines[15]. From 2003 through 2005, efforts on the part of the Louisiana Public Service Commission and a collaborative group of companies referred to as W.E.S.T. LLC investigated the potential of wind energy in Louisiana and sparked the creation of HB 428 - Louisiana's wind energy legislation. The studies conducted by W.E.S.T. in 2004 also concluded that approximately 1017 of 5200 oil and gas rigs offshore of Louisiana are viable structures for wind turbine placement[16].

In HB 428, specifications for wind energy production are outlined. It states that the State Mineral Board will be responsible for selling leases of state land to be used in the production of energy derived from wind, and that they will also manage the fees associated with these efforts. Also any leases requested for development of wind energy must be submitted to the State Mineral Department who then sends it to the Department of Natural Resources. Leases are subject to a public bid, and minimum amounts are specified by the State and Federal Government. Lastly, an "electric power production royalty" is applicable to any lease used for wind energy production; this means that the state will set a dollar revenue amount to each individual turbine and require that the installed turbines meet that royalty and that the state has the authority to take the royalty as a sort of fiscal payment for use of its land.

Essentially what this means is that the most efficient, most productive turbines are going to win the legislative bid for an offshore turbine lease. In future years, when more outside companies are looking to expand their wind turbine farms and business reach, these royalties will be much more relevant to the development of new wind energy farms. If the legislature sees that a Spanish or Chinese company will give more royalties per acre of water with turbine placement then naturally that company will win the bid-however, this is disadvantageous for local businesses which rely on power provided by local oil and gas companies. This is the reason why we must support the development of wind turbines by Louisiana based companies; so that the opportunity is not given to foreign investors and, consequently, the ben- efits as well.

\section{Conclusions}

This paper discussed how wind energy has shown noteworthy potential as an excellent form of renewable energy. The expansion of the American turbine manufacturing industry has spurred the growth of this power source, and foreign countries are not blind to this trend either. Germany, China, France, Spain, and the U.S. are all producing larger percentiles of wind generated energy each year, and showing positive signs of continued expansion and growth in those fields. Not only does the incentive of cleaner air and longevity of electrical production entice the public, but also the jobs which become available in this industry, from manufacturing and maintenance to legislation and marketing, make wind energy a viable choice for new energy systems. Louisiana, however, has shown little to no motivation in working towards implementing or integrating into these technologies; which is largely due to legislative and cultural, oil and gas, barricades. There should be a rethinking on the part of Louisiana investors as to what is important to for their state, the price of their electricity or the condition of their waters. Based on this paper, a broad prospect of application of wind energy and power in Louisiana is anticipated.

\section{REFERENCES}

[1] P.W. Carlin, A.S. Laxson, E.B. Muljadi, "The history and state of the art of variable-speed wind turbine technology", Technical Report, National Renewable Energy Laboratory (NREL), February 2001, Golden, Colorado

[2] http://nuclearfissionary.com/2010/04/02/comparing-energy-c osts-of-nuclear-coal-gas-wind-and-solar/

[3] E. Peltola, M. Marjaniemi, H. Stiesdal, J. Jarvela, "An ice prevention system for the wind turbine blades", Proceedings of 1999 European Wind Energy Conference, 1-5 March, 1999, Nice, France, 1034-1037

[4] N. Hatziargyriou, A. Zervos, "Wind power development in Europe", Proceedings of the IEEE, 89(12), 2001, 1765-1782

[5] http://www.petervaldivia.com/technology/energy/image/win d-turbine.jpg

[6] http://ewea.org/fileadmin/ewea_documents/documents/statist ics/2008_wind_map.pdf

[7] www.cwpc.cn

[8] R. Hodum and L. Schwartz, "China's wind power industry: localizing equipment manufacturing", Renewable Energy World: July 182009

[9] R. Wiser, M. Bollinger, Annual Report on U.S. Wind Power Installation, Cost, and Performance Trends: 2007, Energy Efficiency and Renewable Energy, U.S. Department of 


\section{Energy, 2008}

[10] Annual Wind Industry Report, American Wind Energy Association (AWEA), Washington D.C., 2008

[11] " $20 \%$ wind energy by 2030 - increasing wind energy's contribution to U.S. electricity supply", Energy Efficiency and Renewable Energy, U.S. Department of Energy, July 2008

[12] Annual Wind Industry Report, American Wind Energy Association (AWEA), Washington D.C., 2009

[13] "The economics of wind energy", American Wind Energy Association (AWEA) Report, Washington D.C., February 2005.

[14] B. Crouch, "Offshore Louisiana wind power", Louisiana
Energy Topic, Technology Assessment Division, Louisiana Department of Natural Resources, Baton Rouge, LA, December 2004

[15] M. French, "Evaluating wind energy potential in Louisiana", Technical Report, Research and Development Division, Louisiana Department of Natural Resources, Baton Rouge, LA, September 1981

[16] B. Crouch, "History and recent development in Louisiana wind energy", Technical Report, Technology Assessment Division, Louisiana Department of Natural Resources, Baton Rouge, LA, February 2005

[17] "Word Wind Energy Report 2010", World Wind Energy Association, February, 2011 